\title{
Virulence Factors of Yeasts Isolated From Oral Lesions
}

\author{
Nia'am N. Jammil* ${ }^{\star}$ Manahil M. Yehia** \\ *department of Microbiology, Collage of Medicine, University of Nineveh, Mosul, Iraq. \\ ** department of Microbiology, Collage of Medicine, University of Nineveh, Mosul, Iraq. \\ Correspondence: neamnafea@gmail.com
}

(Ann Coll Med Mosul 2019; 41 (2):170-177).

Received: 18 ${ }^{\text {th }}$ Apr. 2019; Accepted: $8^{\text {th }}$ Dec. 2019.

\begin{abstract}
Objectives: To detect the virulence factors of yeasts which are proteinase and phospholipase which have important role in the pathogenesis of oral lesions.
\end{abstract} Patients and methods: This study included 120 children manifested with oral lesions admitted to the Consultating Clinic and Medical Wards of $\mathrm{Ibn}$ - Sina and Ibn Al - Ather Teaching Hospitals in addition to Neonatal Care Unit of $\mathrm{Al}$ - Battol Teaching Hospital. Samples collected during the period from December 2012 - May 2013. Control group was 60 apparently healthy children from whom oral swabs 'were obtained. Identification' of' the isolated yeasts were conceded by "direct examination, culture, biochemical tests and API - $20 \mathrm{C}$ system, then detection of' protienase and phospholipase of yeasts isolated from oral lesions".

Results: Candida albicans isolates have a high expression rate for the production of proteinase (95.3\%) and phospholipase $(97.1 \%)$ in comparison to the other candida and yeast species with a significant difference $(p=0.001)$.

Conclusion: The isolates produce two important virulence factors namely proteinase and phospholipase significantly more in Candida albicans than other yeasts.

Keyword: Virulence factors, candida species, oral lesions.

\section{عوامل الفوعة للخمائر المعزولة من آفات الفم}

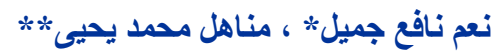 \\ *فرع الاحياء المجهرية، كلية الطب، جامعة نينوى، موصل ** فرع الاحياء المجهرية، كلية الطب، جامعة الموصل، الموصل، العراق
}

الهُف من الاراسة: الكثف عن عوامل الفَوعَة للخمائر وهي إنزيم البروتينياز و إنزيم الفسفوليباز ممن لهم دور مهم في سير مرض آفات الفم. عينات الدراسة وطر ائق العمل: تضمنت الدراسة 120طفل ظهرت عليه أفات الفم والذين بر اجعون العيادة الاستشارية والردهات

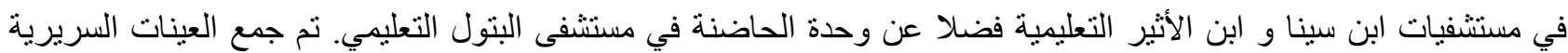

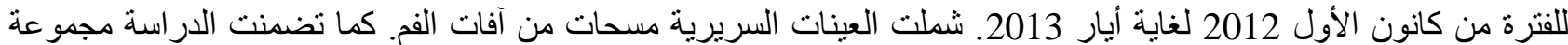
السيطرة التي شملت 60 من الأطفال الأصحاء وتم الحصول منهم على 60 مسحة فموية. تم تمييز الخمائر المعزولة بواسطة الفحص المباشر, الزرع, الفحوصات الكيميحيوية واستخدام نظام API - 20 C ومن ثم فحص إنزيم البروتيناز و الفسفوليباز

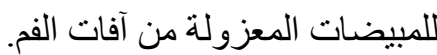

النتائج: أظهرت النتائج بأن C.albicans أعطت أعلى نسبة معبرة في إنتاج إنزيم البروتيناز(95.3\%) و الفسفوليباز(97.1)

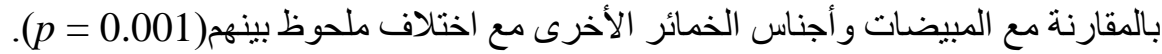

C. الاستتناج: العزلات أنتجت نوعين من عوامل الفوعة وهي إنزيم البروتينتاز و الفسفوليباز وهي الأكثر دلالة في عزلات الاتئن albicans 


\section{INTRODUCTION}

andida species are commonly in attendance in the oral flora as a parasite as well as in nature as saprophyte ${ }^{1}$. beneath confident physiological and pathological situation, the yeasts may modify status from that of commensal to a pathogen predominantly in debilitated patient ${ }^{2}$. Oral candidiasis is a warning of impaired local or systemic defense mechanisms. The chief restricted predisposing factors are concentrated saliva secretion, mucosal lesions, decreased blood distribution in the mucosa due to radiation therapy ${ }^{3}$. The general predisposing factors are diabetes mellitus, chronic illnesses ${ }^{4}$, acquired or inborn immunodeficiency, malignancies, and malnutrition $^{5}$. The iatrogenic factors like wide spectrum antibiotics, corticosteroid therapy chemotherapy and local trauma ${ }^{6}$.

The development of oral candidiasis is the result of imbalance between fungal virulence factors and host's defense ${ }^{2}$. Fungal virulence factors are essential for the conversion from colonization to illness. Extracellular hydrolytic enzymes seem to play an important role in candida overgrowth as these enzymes facilitate adherence and tissue penetration ${ }^{7}$. Among the the majority significant hydrolytic enzymes produced by candida are phospholipase and proteinase which play a important role in pathogenesis ${ }^{8}$. The secreted phospholipase and proteinase are not limited to Candida albicans only but their attendance have been demonstrated in other non-Candida albicans species as C. glabrata and C.tropicalis ${ }^{9}$.

\section{PATIENTS AND METHODS}

Patients: One hundred and twenty children manifested with oral lesions characterized by the presence of removable creamy white patches or red atrophic patches in the mouth were enrolled in the study. Males were $59(49.2 \%)$ and females were $61(50.8 \%)$. The age of the studied children ranged from 2 days -12 years.
Control group: consist of 60 apparently healthy children. They were $29(48.3 \%)$ males and $31(51.7 \%)$ females. Their ages ranged between 3 days -12 years. Sex and age were matched with the patients group.

All samples were collected from the children admitted to the Consultating Clinic and Medical Wards of Ibn - Sina and Ibn - Al - Ather Teaching Hospitals in Mosul in addition to the Neonatal Care Unit of Al - Batool Teaching Hospital in Mosul. The clinical specimens were collect during the period from December 2012 - May 2013.

\section{Processing of the clinical specimens}

"Swabs were cultured on Sabouraud dextrose agar media and brain-heart infusion blood agar media for primary isolation. Direct examinations were done by Gram stain and $20 \% \mathrm{KOH}$ mount. Positive culture underwent further identification as germ tube production, chlamydospore formation, and API - 20 C system tests. Final test of virulence factors detection including phospholipase and proteinase was done ".

\section{Detection of virulence factors:}

\section{1 - Phospholipase}

Extracellular phospholipase activity was detected by inoculation of $10 \mu \mathrm{l}$ of the yeast suspension and incubated at $37^{\circ} \mathrm{C}$ intended for 4 days. ${ }^{10,} 11$ "Phospholipase activity (Pz) was measured by dividing the colony diameter (Dc) over colony diameter plus precipitation zone diameter (Dz) by: $\mathrm{Pz}=\mathrm{Dc} / \mathrm{Dc}+\mathrm{Dz} .{ }^{1,}{ }^{12}$ The results were subdivided into four categories : $\mathrm{Pz}=$ 1 (Negative); $\mathrm{Pz}=0.9-1(+) ; \mathrm{Pz}=0.89-0.80$ $(++) ; \mathrm{Pz}=0.79-0.70(+++) ; \mathrm{Pz} \leq 0.69(++++)$. Accordingly, a low $\mathrm{Pz}$ value indicates stronger enzyme activity". $1,13,14,15$

\section{2 - Proteinase}

The extracellular activity of secreted aspartyl proteinase was detected by a small portion of isolated yeast colony (grown on Sabouraud dextrose agar for 48 hours) was suspended in yeast extract broth, $10 \mu \mathrm{l}$ of the suspension was placed in a well punched on the surface of bovine serum albumin agar. The inoculated plate was 
incubated at $37^{\circ} \mathrm{C}$ then checked for opacity around the well up to 3 days. "The proteinase activity $(\mathrm{Pz})$ is defined at the ratio of colony diameter (Dc) and colony diameter plus degradation zone diameter $(\mathrm{Dc}+\mathrm{Dz})$ by: $\mathrm{Pz}=\mathrm{Dc}$ / Dc + Dz . ${ }^{14}$

The low $\mathrm{Pz}$ the high production of the enzyme. The scoring was carried out by determination of the proteinase zone value as for phospholipase ${ }^{13}$.

\section{Statistical analysis}

The data were analyzed statistically by using tables, pie, and bar charts according to ${ }^{16}$ :

1. Standard statistical methods were used to describe the results of: (mean, standard deviation (SD), number, and percentage).

2. Unpaired $\mathrm{t}$ - test.

3. Proportion test and Fisher's exact test were used to find out the relationship between isolated C.albicans and other species from oral samples and from other sources; they were used to find out the relationship between proteinase and phospholipase.

4. The statistical results were considered significant at $p \leq 0.05$.

\section{RESULTS}

\begin{tabular}{ccccc}
\hline & \multicolumn{3}{c}{ Virulence Factors } \\
\cline { 2 - 4 } Yeast Species & Proteinase & Phospholipase \\
& & & & \\
& No. & $\%$ & No. & $\%$ \\
C. albicans & 81 & 95.3 & 67 & 97.1 \\
& & & & \\
\hline Other species & 4 & 4.7 & 2 & 2.9 \\
& & & & \\
\hline Total & 85 & 100 & 69 & 100 \\
\hline
\end{tabular}

Table 1: Percentage of the virulence factors produced by Candida albicans and other species isolated from oral lesions.
A significant difference between $C$. albicans and other yeast species in the ability of production of virulence factors at $p=0.001$ using Proportions and Fisher's exact test.

Table 2: Types of yeast species isolated from oral lesions with scoring of their virulence factors.

\begin{tabular}{lccc}
\hline Yeast species & $\begin{array}{c}\text { Total } \\
\text { No. }\end{array}$ & Virulence Factors \\
\hline & & Proteinase & Phospholipase \\
& & $16(+)$ & $\mathbf{2 5}(-)$ \\
C. albicans & 92 & $8(++)$ & $\mathbf{1 1}(++)$ \\
& & $10(+++)$ & $\mathbf{1 3}(+++)$ \\
C. tropicalis & 2 & $1\left(_{(++)}\right.$ & $\mathbf{2 9}(++++)$ \\
& & & - \\
C. parapsilosis & 2 & - & -
\end{tabular}

C.guilliermondii $\quad 1 \quad++++\quad-$
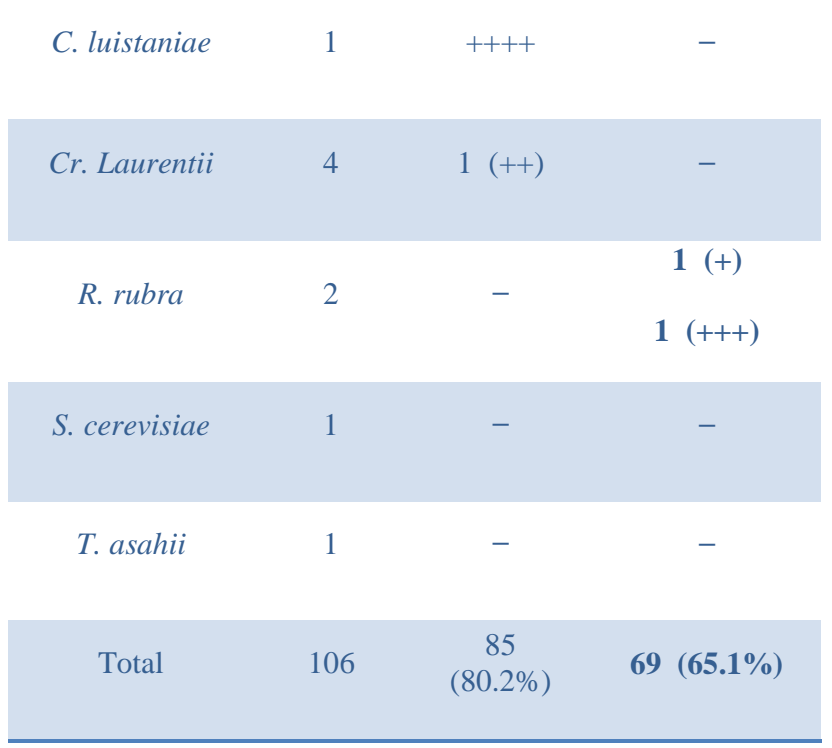

A significant difference between proteinase and phospholipase using Proportions test and Fisher's exact tests $(p=0.012)$. 
Table 3: Candida species isolated from control group concerning virulence factors.

\begin{tabular}{|c|c|c|c|}
\hline \multirow{2}{*}{$\begin{array}{c}\text { Yeast } \\
\text { Species }\end{array}$} & \multirow{2}{*}{$\begin{array}{l}\text { Total } \\
\text { No. }\end{array}$} & \multicolumn{2}{|c|}{ Virulence Factors } \\
\hline & & Proteinase & Phospholipase \\
\hline \multirow{3}{*}{ C. albicans } & & $5(-)$ & $10(-)$ \\
\hline & 18 & $5(+)$ & $5(+)$ \\
\hline & & $8(++)$ & $3(++)$ \\
\hline C. guilliermondii & 2 & - & - \\
\hline C. parapsilosis & 1 & ++ & - \\
\hline C. tropicalis & 1 & - & - \\
\hline C. Iusitaniae & 1 & - & - \\
\hline Total & 23 & $\begin{array}{c}14 \\
(60.9 \%)\end{array}$ & $8(34.8 \%)$ \\
\hline
\end{tabular}

No significant difference between proteinase and phospholipase according to proportions test and Fisher's exact test $(p=0.067)$.

\section{Proteinase}

\section{a. Scoring of yeasts' proteinase isolated from} oral lesions

Out of the 106 isolated yeasts, 85(80.2\%) produced proteinase enzymes with different scoring. From the 92 isolates of $C$. albicans, 81 isolates produced proteinase, though 47 isolates of them showed a stronger activity of proteinase production with $4+$ scores, followed by (10) isolates with $3+$ scores, (8) with $2+$, and (16) with only $1+$ scoring. The other 4 candida species showed different scoring (Table 8). On the other hand, the other 8 isolated yeasts species, only one isolate of $\mathrm{Cr}$. laurentii showed $2+$ score for the production of proteinase enzyme Table 2 and Figure 1 .

\section{b. Scoring of yeasts' proteinase isolated from control group}

Out of 23 isolates of 5 candida species, only $14(60.9 \%)$ produced proteinase. Thirteen were $C$.albicans. Concerning scoring eight isolates had enzymatic activity of $(++)$ and only 5 with $(+)$ score. The last one $C$. parapsilosis had an enzymatic activity of $(++)$ scoring Table 3 .

2. Phospholipase

a. Scoring of yeasts' phospholipase isolated from oral lesions

Out of 106 yeast isolates, only $69(65.1 \%)$ produced phospholipase. Only C.albicans produced the enzyme. The 67 isolates of $C$. albicans produced the enzyme with different scoring that (29) isolates with an enzymatic activity of $4+$, followed by $13(3+), 11(2+)$, and $14(+)$. Among the 4 species of the other yeasts, only 2 isolates of $R$. rubra showed only one score of enzymatic activity and only 1 with (+++), Table 2 and Figure 2.

b. Scoring of yeasts' phospholipase isolated from control group

Phospholipase enzyme was produced from 8 isolates of C. albicans (34.8\%) out of 18. Concerning enzymatic scoring, 3 isolates with $(++)$, and only 5 with (+). The others Candida species did not produce the enzyme Table 3 .

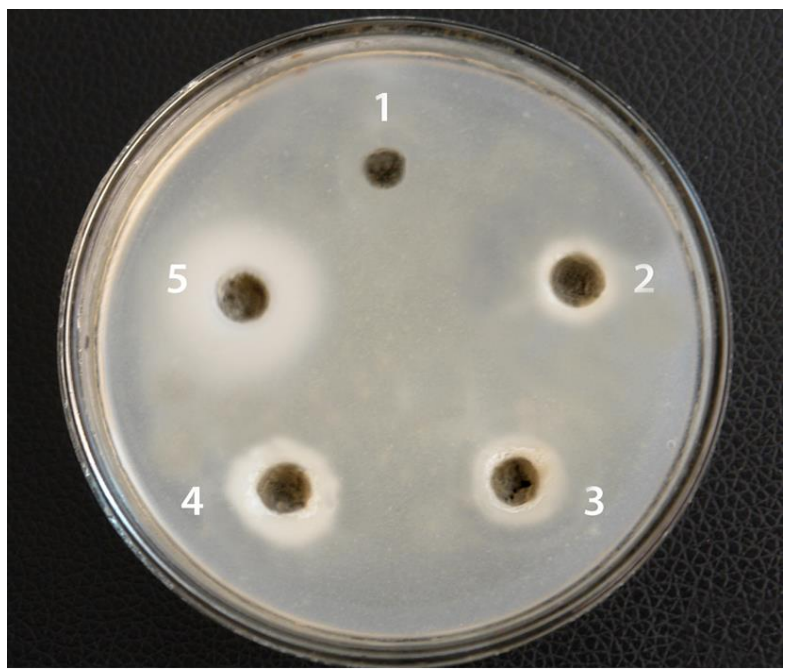

Figure 1: The scoring of proteinase enzyme produced by yeasts on bovine serum albumin medium
1. negative
2. $+=$ low active
3. $++=$ moderate active
4. $+++=$ active
$5 .++++=$ highly active 


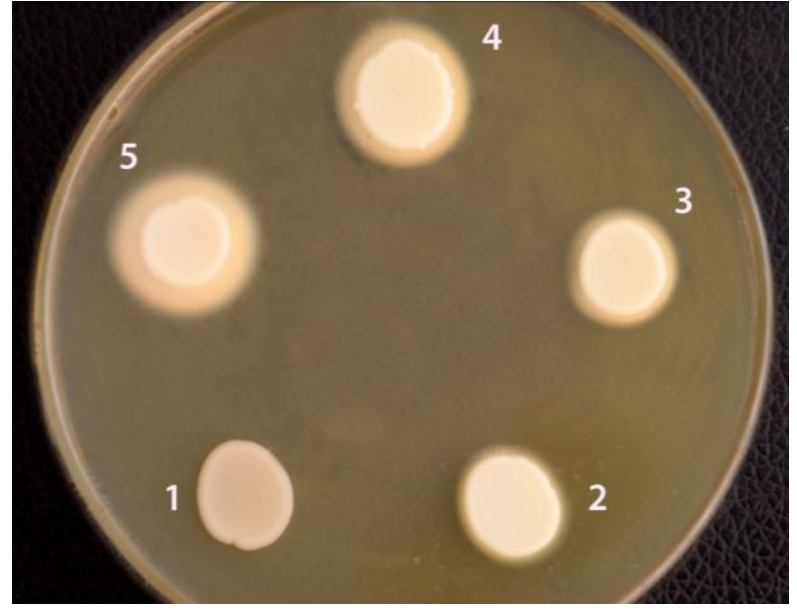

Figure (2): The scoring of phospholipase enzyme produced by yeasts on egg yolk medium

1. negative

2.+=low active

3.++=moderate active

4. $+++=$ active

$5 .++++=$ highly active

\section{DISCUSSION}

\section{Virulence Factors}

Fungi are able to cause a disease and to overwhelm the host defense system because of possessing several genes and proteins which are associated with the pathogenicity; they are called virulence factors. ${ }^{17}$

Extracellular secreted enzymes of microbial pathogens have gained considerable attention due to their potential roles in pathogenesis and as possible targets for future antimicrobial therapies. ${ }^{18}$

Kantarcioglu and Yucel (2002) reported that the most significant hydrolytic enzymes formed by candida are proteinase and phospholipase which play a major role in pathogenesis. ${ }^{19}$ The role of these two hydrolytic enzymes in $C$. albicans and other yeast species seem to be related to species virulence. $^{20}$

\section{Proteinase Activity}

In the present study, the isolates from the oral lesions that produced proteinase enzymes with different scoring were $C$. albicans, $C$. tropicalis, $C$. guilliermondii, and $C$. luistaniae where as $C$. parapsilosis did not produced such enzyme. On the other hand, concerning control group, $C$. albicans and $C$. parapsilosis were produced the enzyme, while $C$. guilliermondii, $C$. tropicalis, and
C. luistaniae did not. investigators mentioned that $C$. albicans, C.glabrata C. tropicalis, C. guilliermondii, and C. luistaniae were isolated in their study from control group and produced proteinaseenzyme. ${ }^{21}$

In this current study, out of the 92 C. albicans isolates, 81 produced proteinase enzyme from this the higher activity of proteinase was recorded mainly for C.albicans (95.3\%) isolated from oral thrush in comparison with control group. This is confirmed by previous study where 26 (66.6\%) isolates of $C$. albicans exhibited strong proteinase activity detected from clinical sources (urine and saliva) in comparison with $4(13.3 \%)$ isolates from throat swabs of the normal healthy control. Tsang and Colleagues (2007) reported that proteinase creation from the diseased patients when compared to healthy individuals was significantly larger in C. albicans isolated. ${ }^{22}$

In this study, the greater part of $C$. albicans enzyme producers were measured to have very physically powerful activity. From the 81 isolates of $C$. albicans with positive proteinases activity, 47 showed the highest activity with scoring of $(4+)$ as (proteinases activity zone), followed by 10 isolates with scoring of $(3+), 8$ with $(2+)$ and 16 with only $(+)$ activity (Table 2). Oksuz and Colleagues (2007) reported different frequencies of proteinase activity ranged from $(4+)$ to $(1+)$ but the highest value within the range of $3+.^{21}$ There was numerous reports representative invasive strains of $C$. albicans produced extensively more extracellular enzymes activity than the commensal strains do. ${ }^{10,23}$

Regarding the 4 NCAC species that were isolated during the study from oral lesions, each of C. guilliermondii and C. luistaniae showed high activity of proteinase enzyme (4+), one out of 2 isolates of $C$. tropicalis showed $2+$ scoring, while the 2 isolates of $C$. parapsilosis did not show any activity. The secreted aspartyl proteinases are not restricted to $C$. albicans and their presence has been confirmed in C.tropicalis, C. parapsilosis, and $C$. guilliermondii. ${ }^{9}$ In recent years, species of candida other than $C$. albicans, which were in the past considered as a fewer or non - virulent, have been occupied more frequently in human sickness. ${ }^{15}$ 
Kantarcioglu and Yucel (2002) reported that protease activity was observed in addition to $C$. albicans, in C. kefyr, C. parapsilosis, and C. tropicalis isolates. ${ }^{19}$ Protease activity of $C$. albicans isolates were establish to be $(56.7 \%)$ elevated more than that of NCAC isolates (43.9\%) but the variation was not statistically significant. ${ }^{21}$ These results were not in agreement with this of the current study that the activity of $C$. albicans $(95.3 \%)$ was statistically different from NCAC $(4.7 \%)$ in the production of proteinase enzymes.

Concerning the other yeast species, non of which showed proteinase activity except one out of the 4 isolates of Crypyocpccus laurentii which showed an activity of $(2+)$ scoring. It was reported that cryptococcal infection due to species other than Cryptococcus neoformans may be considered an emerging infection, and proteinase secretion was a virulence factor of $\mathrm{Cr}$. neoformans. ${ }^{24}$ Cryptococcus laurentii was not reported as producer of proteinase enzyme when isolated from clinical specimens. Moreover, it was mentioned that none of $38 \mathrm{Cr}$. laurentii isolates that are identified from pigeon droppings and surrounding hospital areas exhibited proteinase activity. ${ }^{25}$

\section{Phospholipase Activity}

Out of 106 studied yeast species, phospholipase activity was noticed only in 69 $(65.1 \%)$ isolates. Kantarcioglu and Yucel (2002) report more constructive rate of phospholipase activity from patients with invasive yeasts disease. In this study, it was appeared that proteinase activity (80.2\%) was higher than this of phospholipase $(65.1 \%)$ from the yeasts with a significant difference $(p=0.012)$. This is in consistence with other report that 50 of the isolated yeast species was phospholipase positive and 64 was protease positive.

In this study, from the 92 C. albicans isolates, only 67 produced phospholipase enzyme with different activities, while no other candida species produced this enzyme. Ghannoum (2000) reported that only $C$. albicans was capable to create phospholipase ${ }^{9}$. Now - a day, it is known that the other species of candida also create the enzyme usually in smaller amount. ${ }^{26}$ The enzymatic activity was more distinct in C.albicans among $100 \%$ phospholipase, in contrast to NCAC species which produced only $29.6 \%$ of phospholipase. ${ }^{13}$
Pinto and Coworkers (2008) reported 99.4\% isolates of $C$. albicans with phospholipase activity. ${ }^{26}$ However, other researchers state that other candida species such as $C$. glabrata, $C$. guilliermondii, and $C$. tropicalis secreted smaller amount of phospholipase. ${ }^{14,21}$ Moreover, a higher frequency of C. albicans (92.3\%) produced phospholipase. $^{15}$

In comparison to the control group, phospholipase produced by only 8 isolates of $C$. albicans out of 23. This result is in consistence with this by Basu and Coworkers (2003) who reported that $49 \%$ were clinical isolates of $C$. albicans confirmed phospholipase activity while only two since the normal healthy personnel were positive for this enzyme. ${ }^{27}$ There were more than a few reports indicating invasive strains of $C$. albicans produced extensively additional extracellular enzymes activity than the commensal strain do. ${ }^{10,27}$ Hence, the levels of phospholipase and protease activities in commensal isolates was found to be lesser than the level reported in clinical Candida species. ${ }^{23}$

As shown in Table 2, the highest amount of phospholipase enzyme was produced from 29 out of 67 C. albicans isolates with $4+$ scoring, followed by 13 isolates with $3+$ scoring. Mahmoudaabadi and Coworkers (2010) reported that 61 out of 72 yeast isolates produced large amount of the enzyme with score of $4+$, and 7 isolates with $3+$ score.$^{28}$ Special frequencies of phospholipase have been report from different candida species from diverse different sites. ${ }^{19,29}$

In a study conducted by Vidotto and Coworkers (1999b) phospholipase activity was found most frequently in oral cavity isolates. ${ }^{30}$ An elevated phospholipase production is associated with an improved capability to adherence and a superior death rate in animal models. ${ }^{31}$

In the present study, only the 2 isolated yeasts of $R$. rubra showed phospholipase activity while the other isolated yeasts showed no such activity. This result in agree with that of Mayser and Coworkers (1996) who showed that in addition to C. albicans, a total of 110 strains of 16 other yeast species were investigated for possible phospholipase production, only $R$. rubra showed the enzyme activity. ${ }^{31}$ Rhodotorula rubra has infrequently been confirmed as a pathogen in human. It was believed that factor such as the 
condensed growth at $37^{\circ} \mathrm{C}$, lack of dimorphism and little capability to adherence reduce important of elevated phospholipase activity in $R$. rubra as a pathogenicity determinant. ${ }^{32}$ In the current study, neither $S$. cerevisiae nor $T$. asahii produced phospholipase or proteinase enzymes which is in agreement with Dag and Cerikeioglu (2006) who reported that non of the 48 strains of S.cerevisiae and $T$. asahii showed phospholipase nor proteinase activity, while all were esterase producer. $^{33}$

Colombo and Coworkers (2011) reported that Trichosporon species be able to signify the most second or third frequent non-candida yeast infection cause persistent diseases in patients ${ }^{34}$, but little reports have address the virulence factor of this species. ${ }^{35,36}$

\section{CONCLUSION}

Higher frequencies with different scorings of proteinase $(80.2 \%)$ and phospholipase $(65.1 \%)$ are detected in the yeast isolated from oral lesions in children compared to healthy control group.

\section{REFERENCES}

1. Moris DV, Melhem MSC, Martins MA, et al. Oral Candida species colonization in human immunodeficiency virus - infected individuals. J Venom Anim Toxins Incl Trop Dis 2008; 14:22457.

2.Bensadoun R-J, Patton LL, Lalla RV, Epstein JB.Oropharyngeal candidiasis in head and neck cancer patients treated with radiation. Support Care Cancer 2011; 19:737-44.

3.Rautemaa R, Rusanen $\mathrm{P}$, Richardson $\mathrm{M}$, Meurman JH. Optimal sampling site for mucosal candidosis in the oral cancer patients is the labial sulcus. J Med Microbiol 2006; 55:1447.

4.Barker FJ. Isolation and Identification of fungi. In: Medical Microbiological Techniques butterworth and Co.Ltd. London 1980; pp: 217, 222, 496, 7.

5.Meurman O, Koskensalo $A$ and Rantakokko Jalava K. Evaluation of Vitek 2 for identification of yeasts in the clinical laboratory. Clin Microbiol. Infect 2006; 12: 591-3.

6.Kaul KK, Shah JP and Pohowalla JN. Oral moniliasis in the newborn and neonatal morbidity. Indian J Pediatr 1960; 27:115-24.
7.Schaller M, BorelliC, Korting HC, Hube B. Hydrolytic enzymes as virulence factors of Candida albicans. Mycoses 2005; 48:365-77.

8.Kumar VG, Latha $\mathrm{R}$, Vedhagiri $\mathrm{K}$, et al. Phospholipase $\mathrm{C}$, proteinase and hemolytic activity of candida species isolated from pulmonary tuberculosis patients. Med Mycology 2009a; 19:3-10.

9.Ghannoum MA. Potential role of phospholipase in virulence and fungal pathogenesis. Clin Microbiol Rev 2000; 13:122-43.

10.Yucel A and Kantarcioglu AS. The determination of some virulence factors (phospholipase, protease, germ tube formation and adherence) of Candida albicans and the correlative relationship of these factors.Turk $\mathrm{J}$ Infect 2001; 15:517-25.

11.Samaranayake $\mathrm{YH}$, Dassanayake RS, Jayatilake JA, et al. Phospholipase B enzyme expression is not associated with other virulence attributes in Candida albicans isolates from patients with human immunodeficiency virus infection. J Med Microbiol 2005; 54:58393.

12.Price MF, Wilkinsone ID and Gentry LO. Plate methods for detection of phosolipase activity in Candida albicans. Saboraudia 1982; 20; 7 - 14.

13.Kumar CPG, Kumur SSJ and Menon T. Phospholipase and proteinase activities of clinical isolates of candida from immunocompromised patients. Mycopathologia 2006; 161:213-8.

14.Mohandas $V$ and Ballal $M$. Distribution of candida species in different clinical samples and their virulence: Biofilm formation, proteinase, phospholipase production: A study in hospilalized patients in southern India. $J$ Global Inf dis 2011; 3:4-8.

15.Sachin CD, Ruchi K and Santosh S. In vitro evaluation of proteinase, phospholipase and haemolycin activities of candida species isolated from clinical specimens. Int $\mathrm{J}$ Med Bio Med Res 2012; 1:153-7.

16.Dunn OJ and Clark VA. Basic statistic: a primer for the biomedical sciences. $4{ }^{\text {th }}$ Ed. John Wiley, New Jersey 2009; Chapter 8. Pp.46-561.

17.Tomee JFC and Kauffman HF. Putative virulence factors of Aspergillus fumigates. Clin Exp Allergy 2000; 30: 476-84. 
18.Ge YP, Lu GX, Shen YN, et al. In vitro evaluation of phospholipase, proteinase, and esterase activities of Candida parapsilosis and Candida metapsilosis. Mycopathologia 2011; 172: 429- 38.

19.Kantarcioglu AS and Yucel A. Phospholipase and protease activities in clinical candida isolates with reference to the sources of strains. Mycoses 2002; 45: 160-5.

20.Xu J and Mitchell TG. Geographical difference in human oral yeast flora. Clin Infect Dis 2003; 36: 221-2.

21.Oksuz S, Sahin I, Yildirim M, et al. Phospholipase and proteinase activities in different candida species isolated from anatomically distinct sites of healthy adults. Jpn $\mathrm{J}$ Infect Dis 2007; 60: 280-3.

22.Tsang CS, Chu FC, Leung WK, et al. Phospholipase, Proteinase and haemolytic activities of patients with type 2 diabetes mellitus. J Med Microbiol 2007; 56: 1393-8.

23.Bernardis FD, Sullivan PA and Cassone A. Aspartyl proteinases of Candida albicans and their role in pathogenicity. Medical Mycology 2001; 39: 303-13.

24.Ikeda R, Sugita $\mathrm{T}$, Jacobson ES, et al. Laccase and melanization in clinically important Cryptocaccus species other than Cryptococcus neoformans. J Clin Microbial 2002; 40: 1214-8.

25.Ferreira - Paim K, Andrade - Silva L, Mora DJ, et al. Antifungal susceptibility, enzymatic activity, PCR - fingerprinting and ITS Sequencing of environmental Cryptococcus laurentii isolates from Uberaba, Minas Gerais, Brazil. Mycopathologia 2012; 174: 41-52.

26.Pinto E, Ribeiro IC, Ferreira NJ, et al. Correlation between enzyme production, germ tube formation and susceptibility to fluconazole in candida species isolated from patients with denture - related stomatitis and control individuals. J Oral Pathol Med 2008; 37: 58792.

27.Basu S, Gugnani HC, Joshi S, et al. Distribution of candida species in different clinical sources in Delhi, India, and proteinase and phospholipase activity of Candida albicans isolates. Rev lberoam Micol 2003; 20: 137-40.

28. Mahmoudabadi AZ, Zarrin M and Miry S. Phospholipase activity of Candida albicans isolated from vagina and urine samples. $\mathrm{J} \mathrm{J} \mathrm{M}$ 2010; 3: 169-73.

29.Vidotto V, Kogo - Ito $C Y$ and Milano R. Correlation between germ tube production, phospholipase activity and distribution and serotype in Candida albicans. Rev Iberoam Micol 1999a; 6: 208-10.

30.Vidotto V, Kogo - Ito CY and Garramone A (1999 b). Virulence factors serotype distribution and adherence in Candida albicans. Abstr. The $5^{\text {th }}$ Congress of the European Confederation of Medical Mycology, Mycoses, Dresden, Germany.

31.Mayser $\mathrm{P}$, Laabs $\mathrm{S}$, Heuer $\mathrm{K}-\mathrm{U}$, et al. Detection of extracellular phospholipase activity in Candida albicans and Rhodotorula rubra . Mycopatholgia 1996; 135: 149-55.

32.Bhattacharyya S, Shivaprakash MR, Chakrabarti $A$, et al. Foot bleb infection due to Rhodotorula mucilaginosa in a diabetic patients: Case report and review of the literature. Biomed Res - India 2012; 23: 577-9.

33.Dag A and Cerikcioglu N. Investigation of some virulence factors of Trichosporon asahii strains isolated from the clinical samples of hospitalized patients. Mikrobiyol Bul 2006;40: 225-35.

34.Colombo AL, Padovan ACB and Chaves GM. Current Knowledge of Trichosporon species and Trichosporonosis. Clin Microbiol Rev 2011; 24: 682-00.

35.Di Bonaventura G, Pampilio A, Picciani C, et al. Biofilm formation by the emerging fungal pathogen Trichosporon asahii: Development, architecture,and antifungal resistance. Antimicrob Agents Chemother 2006; 50: 326976.

36.Chagas-Neto TC, Chaves GM and Colombo AL. Update of the genus Trichosporon. Mycopathologia 2008; 166: 121-32. 